\title{
PENINGKATAN LITERASI DIGITAL DAN INOVASI PRODUK SASIRANGAN BAGI IBU-IBU RUMAH TANGGA UNTUK MENINGKATKAN PEREKONOMIAN KELUARGA DI MASA PANDEMI COVID 19
}

\author{
Edlin Yanuar Nugraheni ${ }^{*}$, Muhammad Rahmattullah' ${ }^{2}$, \\ ${ }^{1}$ Program Studi Pendidikan Sendratasik, FKIP, Universitas Lambung Mangkurat \\ ${ }^{2}$ Program Studi Pendidikan Ekonomi, FKIP, Universitas Lambung Mangkurat \\ *E-mail: edlin.nugraheni@ulm.ac.id
}

\begin{abstract}
ABSTRAK
Masih rendahnya kemampuan berkreasi ibu-ibu rumah tangga yang bekerja di pengolahan kain Sasirangan di sekitar unit usaha Mads Sasirangan disebabkan terbatasnya pengetahuan tentang inovasi produk. Kemampuan memasarkan produk secara online menjadi permasalahan lain yang dihadapi akibat terbatasnya literasi digital dalam menunjang kegiatan wirausaha berbasis potensi unggulan lokal. Kegiatan pengabdian ini bertujuan untuk meningkatkan kemampuan inovasi dan literasi digital bagi ibu-ibu pengrajin sasirangan di sekitar unit usaha Mads Sasirangan dalam rangka meningkatkan pendapatan ekonomi rumah tangga khususnya di masa pandemi Covid 19. Metode pengabdian dilaksanakan melalui kegiatan pelatihan dengan pendekatan kooperatifpartisipatif. Hasil pengabdian menunjukkan peningkatan kemampuan inovasi dan literasi digital ibu-ibu rumah tangga yang menjadi sasaran kegiatan dalam mengolah produk berbahan dasar Sasirangan, yang diharapkan akan menunjang dalam memperoleh penghasilan tambahan bagi keluarga.
\end{abstract}

Kata Kunci: Sasirangan, Inovasi Produk, Literasi Digital, Ekonomi Rumah Tangga, Pandemi Covid 19

\begin{abstract}
The low creative ability of housewives who work in Sasirangan fabric processing around the Mads Sasirangan business unit is due to limited knowledge about product innovation. The ability to market products online is another problem faced due to limited digital literacy in supporting entrepreneurial activities based on local superior potential. This project aims to improve innovation and digital literacy skills for sasirangan craftsmen around the Mads Sasirangan business unit in order to increase household economic income, especially during the Covid 19 pandemic. Project methods are carried out through training activities with a cooperativeparticipatory approach. The results of this project show an increase in innovation and digital literacy abilities of housewives who are the target of activities in processing products made from Sasirangan, which are expected to support in obtaining additional income for the family.
\end{abstract}

Keywords: Sasirangan, Product Innovation, Digital Literacy, Household Economy, Covid 19 Pandemic

\section{PENDAHULUAN}

Seni karya kerajinan berkembang pada setiap kelompok masyarakat, pada hakikatnya tidak bisa dilepaskan dari kehidupan sosial dan budaya masyarakat tersebut. Pemanfaatan potensi alam dan lingkungan sebagai produk aktivitas ekonomi memberikan manfaat secara ekonomis dalam pemenuhan kebutuhan hidup. Pada sudut pandang budaya, produk dari aktivitas ekonomi merupakan cerminan budaya yang berkembang di kelompok masyarakat. Cerminan budaya dalam bentuk benda fisik menghasilkan pula nilai seni yang dapat dinikmati selain fungsi dasarnya sebagai barang pemuas kebutuhan masyarakat.

Rasa yang memunculkan sebuah estetika dalam sebuah karya seni, manusia bisa menggunakan berbagai macam cara dan berbagai media yang ada di sekitarnya. Manusia menciptakan beragam kerajinan tangan untuk memenuhi kebutuhan hidup, namun jika pengerjaannya dilakukan dengan penuh perasaan (termasuk dalam penggunaan bahan dan alat), maka hasilnya merupakan karya seni yang bernilai estetika. Kerajinan asesoris kain sasirangan semi sutra dikembangkan dengan memanfaatkan kain perca dari kain sasirangan semi sutra yang memiliki warna yang di ambil dari alam pewarnaannya. 
Sasirangan adalah kain khas Banjarmasin Kalimantan Selatan. Seperti halnya Batik yang dimiliki oleh masyarakat Jawa. Kain Sasirangan merupakan jenis kain sandang yang disebut dengan kain calapan atau kain caluban yang dihiasi dengan warna dan motif tradisional Kalimantan Selatan. Pewarna Kain Sasirangan dari alam, warna merah mengkudu atau merah hati diperoleh dari (kulit atau akar mengkudu atau pace, jinten hirang, pala, merica, cengkeh dan air jeruk sitrun). Warna Kuning tua (lumatan temulawak dan kunyit yang dicampur cuka dan tawas). Warna Hijau diperoleh dari gabungan beberapa bahan alami (kunyit jarak, daun kacang, pohon jahe, nanas hutan, air jeruk dan tawas). Warna hitam (akar pohon kebuau yang direbus bersama kulit buah rambutan dan tanah lumpur). Warna Ungu (biji buah ramania diperoleh dari akar dan bunga karamunting dan diberi air jeruk).

Kerajinan Asesoris Kain Sasirangan adalah kerajinan merangkai dan menggabungkan kain sasirangan dengan bahan lain atau pernik-pernik lain. Kerajinan Asesoris Kain Sasirangan ini antara lain dapat memanfaatkan kain perca sasirangan semi sutra. Meskipun sifat Kain Semi Sutra tersebut relatif lebih lembut, namun untuk menjadi bahan Asesoris siap pakai harus dipilah terlebih dulu sehingga menjadi kontras dan menarik dengan bahan lain. Secara tradisional, bahan Kain Sasirangan tersebut bisa dibuat taplak meja, tutup dispenser, tataan gelas/piring, korden, dan hiasan kamar lainnya.

Pembuat Sasirangan atau pengrajin Sasirangan juga ditemukan di pinggiran sungai Kecamatan Sungai Lulut Kabupaten Banjar Provinsi Kalimantan Selatan. Pinggiran Sungai Lokbaitan merupakan daerah terpadat untuk jalan rayanya, karena untuk menuju ke kota hanya melewati kecamatan sungai lulut diperlukan waktu kurang lebih 1 jam perjalanan melalui darat, dan untuk menuju kota Banjarmasin diperlukan waktu 1-2 jam perjalanan melalui sungai. Selain itu di Sungai Lulut banyak sekali pedagang dipinggiran sungai maupun di daratan. Pembuat / pengrajin sasirangan memproduksi kain sasirangan dirumah sendiri dan menjualkan sendiri dari rumah. Setiap Pengrajin memiliki pelanggan yang sudah tetap untuk dijual lagi.

Kaum perempuan, khususnya para ibu rumah tangga di Kampung Sasirangan Pinggiran Sungai, mempunyai banyak waktu luang setelah mereka selesai melakukan pekerjaan rumah tangga. Pada umumnya mereka sudah memiliki keterampilan dasar menyirang, karena keterampilan itu telah dimiliki secara turun temurun. Hanya saja keterampilan membuat Sovenir dari Kain Perca Sasirangan belum dikembangkan secara maksimal. Mereka hanya membuat produk taplak meja dan produk yang dipergunakan untuk keperluan hiasan rumah. Mereka belum berpikir untuk mengembangkan produk yang diminati konsumen, produk yang bisa dijual di pasaran, baik sebagai Souvenir/asesoris maupun produk fesyen lainnya. Selain itu belum muncul seseorang atau sekelompok orang yang mencoba mengembangkan potensi tersebut. Permasalahan yang dihadapi ibu rumah tangga antara lain sulitnya untuk mengatur pengeluaran dengan dana terbatas sehingga banyak diantara mereka yang membutuhkan penghasilan tambahan atau program penghematan (Andriani, dkk, 2020). Selain itu perempuan selaku ibu rumah tangga sering dihadapkan pada masalah kurangnya pengetahuan dan keterampilan manajemen keuangan (Soegoto, dkk, 2020). Berdasarkan permasalahan yang dihadapi oleh mitra maka tim pengusul IbM merasa ikut bertanggung jawab baik secara moral maupun akademik untuk turut serta membantu mengatasi permasalahan yang mereka hadapi melalui kegiatan IbM ini.

Berdasarkan permasalahan yang dicapai oleh mitra, maka tim pengabdian bekerja sama dengan mitra untuk mengembangkan keterampilan menyirang yang telah mereka miliki. Kewirausahaan mengangkat potensi unggulan daerah saat ini telah menjadi prospek bisnis yang menjanjikan (Nurhikmah, dkk, 2020). Modal dasar berupa keterampilan menyirang yang dimiliki oleh kaum perempuan di Pinggiran sungai Kampung Sasirangan tersebut bisa dikembangkan, apabila mereka dibina dan dilatih untuk membuat berbagai macam produk Souvenir/ asesoris dari perca kain sasirangan semi sutra yang diminati konsumen, yang laku di pasaran, dan produk dibuat mengikuti tren pasar. Pelatihan dan pendampingan pengolahan limbah kain perca sasirangan menjadi produkproduk seperti tas, kantong HP, aksesoris, bros, peci, toples cantik telah dilakukan namun memiliki sasaran pada kelompok rumah tangga di lokasi dengan karakteristik individu dan geografis yang berbeda (Ranti dan Susilawati, 2019) 
Selain itu perlu dibukakan akses untuk pemasaran produk, karena masalah pemasaran merupakan permasalahan klasik yang banyak dihadapi oleh pelaku industri rumah tangga. Akses pemasaran yang paling luas jangkauannya adalah melalui pemasaran online. Oleh karena itu perlu dirintis mata rantai pemasaran, mulai dari pengrajin, pengumpul (koperasi), distributor, dan retail. Pemanfaatan gawai untuk pemasaran online merupakan potensi dalam pengembangan wirausaha (Arifianto, dkk, 2020). Pemanfaatan sarana media social seperti Instagram telah dijalankan pada industry Sasirangan walaupun pada skala yang lebih besar yakni industry rumah tangga seperti Nida Sasirangan (Pratomo, dkk, 2018)

\section{METODE}

Untuk Pelaksanaan kegiatan pengabdian masyarakat Kerajinan Souvenir/Asesoris Kalung dari perca Kain Sasirangan bagi kaum perempuan ibu rumah tangga di Mads Sasirangan Kabupaten Banjar Kalimantan Selatan, dilaksanakan dengan menggunakan metode kooperatif-partisipatif, yang melibatkan partisipasi masyarakat dan kerja sama antara masyarakat dengan tim pengabdian dari perguruan tinggi. Metode yang dilaksanakan berupa:

1. Survai ke lokasi untuk mengurus perizinan, Mads Sasirangan merupakan tempat kegiatan dan waktu pelaksanaan kegiatan.

2. Pembentukan dua kelompok pembaharu yang masing-masing terdiri dari 10 orang, dan beranggotakan perwakilan warga masyarakat dari beberapa RT.

3. Diskusi mengenai rancangan media pemasaran (brosur, iklan, online)

4. Stimulus bahan dan peralatan pembuatan produk asesoris dari tim pengusul pengabdian masyarakat kepada kelompok pembaharu.

5. Komunikasi intensif antara perguruan tinggi dengan mitra.

\section{HASIL DAN PEMBAHASAN}

Mads Sasirangan yang berada di pinggiran sungai dan berada di daerah Sungai Bakung Kab. Banjar. Kegiatan Pengabdian pada masyarakat yang dilakukan oleh tim pengabdian masyarakat yang dilakukan selama 3 bulan dari bulan Agustus - September - Oktober tahun 2021. Tujuan dalam pengabdian ini berupa pelatihan untuk mengenalkan dan memberikan inovasi bentuk karya produk baru, serta melatih masyarakat dan ibu-ibu dari pengrajin sasirangan. Lokasi pengabdian dapat ditempuh dari Kota Banjarmasin kira-kira 1 jam, dengan melewati 3 jembatan besar menuju daerah Sungai Lulut. Apabila menggunakan kelotok (perahu kecil) dari kota sekitar setengah jam, dan masuk atau jalan kaki untuk ke Mads Sasirangan sendiri dari jalan raya kurang lebih 100m,

Mads Sasirangan adalah pengrajin sasirangan di sungai bakung kab. Banjar satu-satunya yang membuat sasirangan secara manual, menjualkan secara personal kain sasirangan dengan cara dipesan hanya pada langganan. Mads Sasirangan apabila dalam pemesanan dalam jumlah besar, maka dibantu oleh ibu-ibu yang ada disekitarnya. Manajemen mandiri dilakukan oleh Mads Sasirangan oleh pemiliknya yaitu bapak Achamd bersama keluarganya. Kekhasan motif yang dipakai Mads Sasirangan sangatlah khas karena disesuaikan dengan pewarnaan yang masih secara alam maupun dengan pewarna kain. Pemesan biasanya menentukan motif, menentukan bahan, panjang kain (2 meter/3 meter), dan jumlah atau banyaknya. 

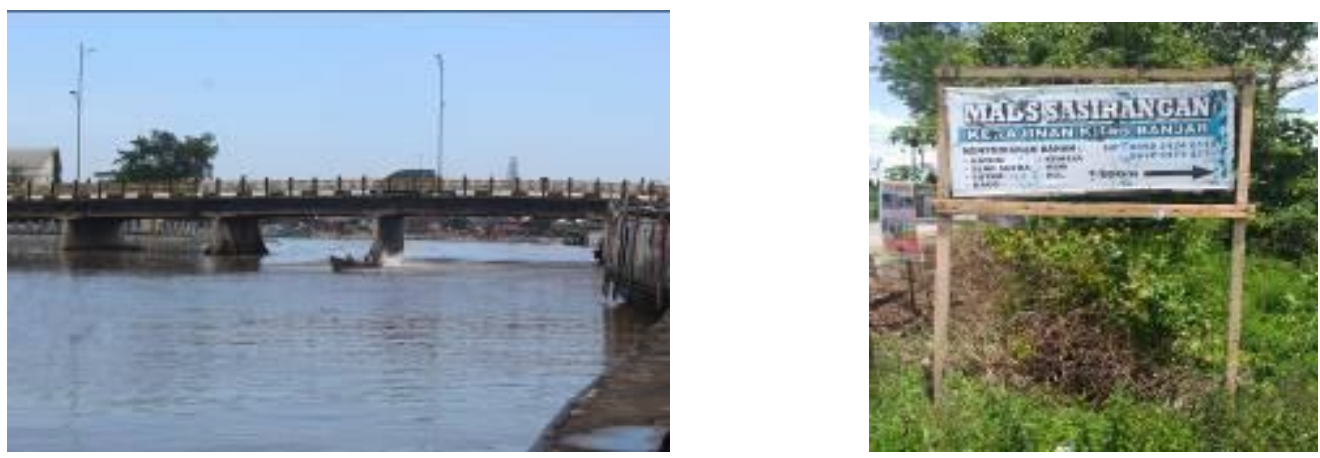

\section{Gambar. Arah menuju Lokasi Mads Sasirangan}

Pelatihan yang dilakukan bersama tim ke daerah pinggiran sungai, yang dekat dengan daerah wisata pasar terapung Lokbaintan. Pengabdian masyarakat yang dilakukan adalah untuk memberikan pelatihan inovasi produk bentuk karya baru, motivasi bagi para pengrajin dan ibu-ibu didaerah Mads Sasirangan yang telah lama menghasilkan kain-kain sasirangan dan memproduksi secara manual. Pelatihan ketrampilan dalam berkreasi akan karya-karya seni yang dinikmati oleh khalayak luas serta mengikuti perkembangan masa sekarang. mengenalkan, membimbing pembuatan sampai dengan pengemasan, serta mengenalkan teknik pemasarannya secara online, sehingga dikenal dan diminati pasar yang lebih luas.

Tahapan Pelatihan Tim Pengabdian Masyarakat dengan praktisi pengrajin Mads Sasirangan di Sungai Bakung Kab. Banjar Kalimantan Selatan

\begin{tabular}{|l|l|c|}
\hline NO. & \multicolumn{1}{|c|}{ Uraian } & \multicolumn{1}{|c|}{ Foto } \\
\hline 1. & Tahap Pendahuluan & $\begin{array}{l}\text { Pengarahan dari pengrajin kain MADS } \\
\text { Sasirangan oleh Bapak Achmad, dan } \\
\text { pengarahan untuk pelatihan dari tim Pengabdian } \\
\text { Masyarakat. }\end{array}$ \\
\hline 2. & $\begin{array}{l}\text { Tahap Pengenalan Bahan } \\
\text { Bahan - Bahan untuk menghiasi dan batu- } \\
\text { berbagai warna serta harga-harga yang dipakai. }\end{array}$ \\
\hline
\end{tabular}


BAKTI BANUA : Jurnal Pengabdian Kepada Masyarakat

Volume 2 No. 1 Mei 2021

e-ISSN : 2722-3736

p-ISSN : 2722-7529

https://ejurnal.stimi-bjm.ac.id/index.php/BBJM/

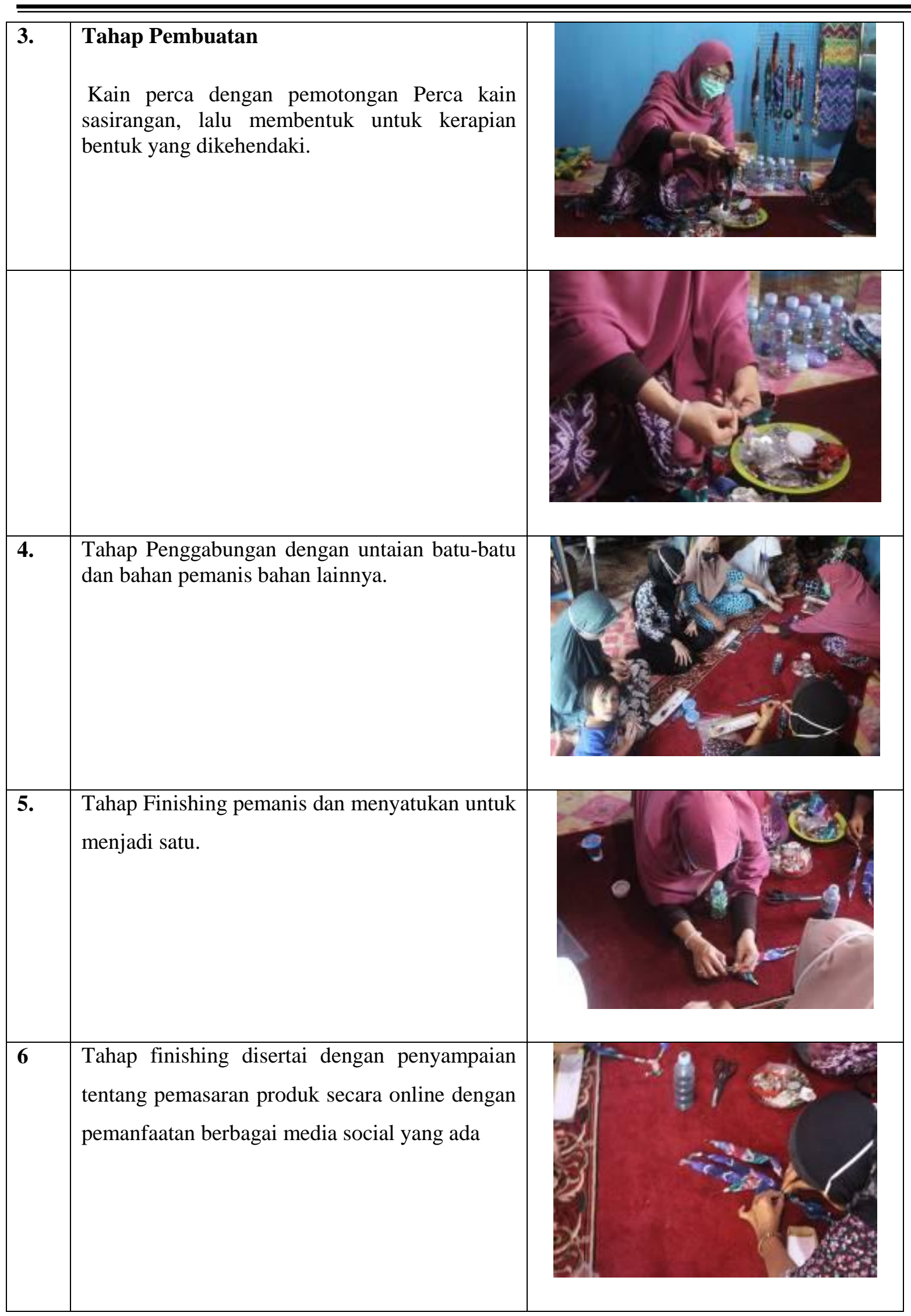

Page $\mid 5$ 


\begin{tabular}{|l|l|l|}
\hline \hline 6. & Tahap selesai & (A) \\
Hasil pelatihan dipakai per -peserta masing- \\
masing yang sudah bisa membuatnya sendiri \\
secara tepat dan baik.
\end{tabular}

Bentuk Prodak-prodak dari dari Hasil Pelatihan yang dari Perca Kain Sasirangan dan batubatuan alam Martapura, sebagai berikut :

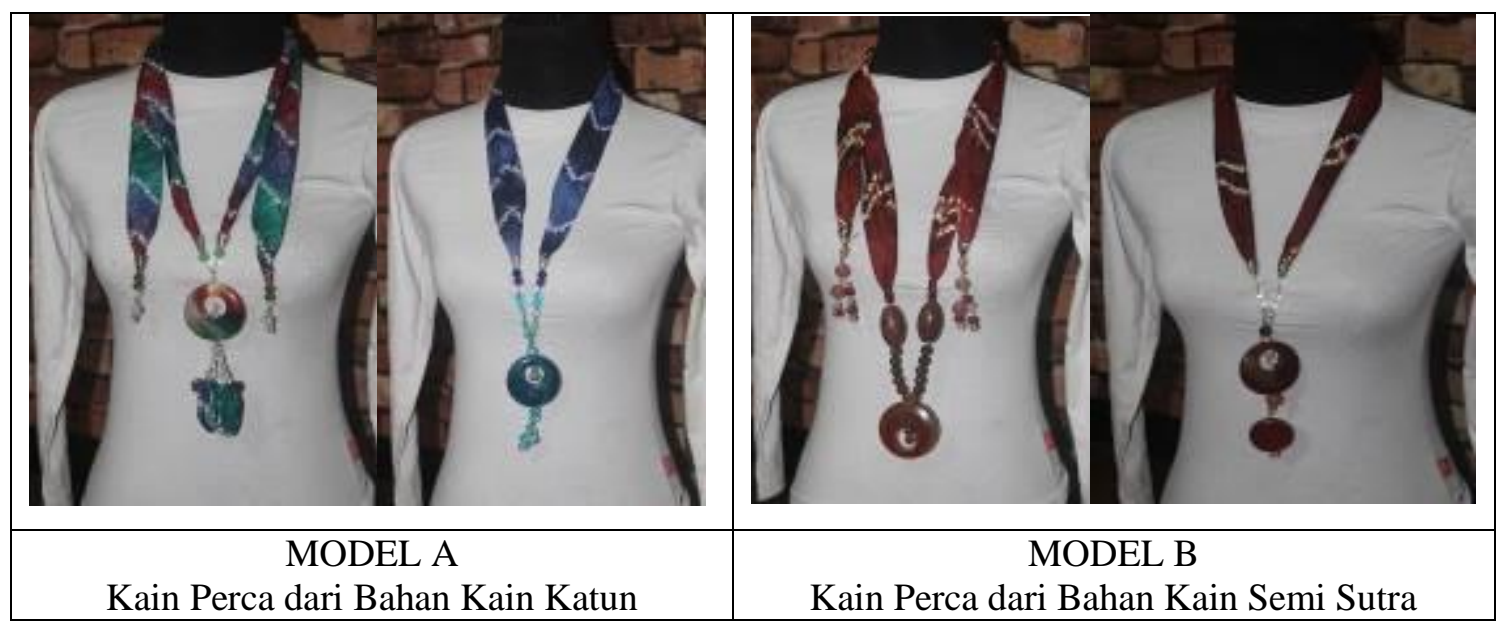

\section{SIMPULAN}

Pengrajin Sasirangan yang berada di Kab. Banjar khususnya di MADS Sasirangan di Sungai Lulut, mulai bisa membuat prodak baru dari kain perca dari kain sasirangan yang bernilai tinggi. Pada masa pendemi ini ibu-ibu yang tergabung dalam MADS Sasirangan menjadi lebih produktif, dimana kain perca sisa dari menjahit, sekarang mulai di produksi lagi untuk menjadi sebuah asesoris kalung yang memiliki nilai yang tinggi yang disukai oleh masyarakat luar sungai lulut. Pelatihan ketrampilan yang didapatkan dengan mengisi waktu luang dan sekarang menjadi sumber pendapatan keluarga. Pemasaran dengan cara online, dengan IG facebook dan WA adalah modal ibu-ibu untuk memasarkan asesoris hasil buatannya untuk menambahi pemasukan keluarga. Juga menjualkan disekitar daerah sungai lulut juga, karena pasar terapung yang mulai sepi karena pandemi ini, maka ibu-ibu mulai belajar membuat dan memasarkan melalui HP online. Teknik pembuatan yang mudah dan dengan bahan yang murah, menambah semangat ibu-ibu untuk lebih berkreatif dalam membuat sasirangan dan kerajinan sasirangan lainnya.

\section{UCAPAN TERIMAKASIH}

Terimakasih pada Dekan FKIP Universitas Lambung Mangkurat yang telah memberikan bantuan Dana pengabdian ini, dan bapak Achmad pemilik Mads Sasirangan, ibu-ibu pengrajin sasirangan yang telah memberikan ijin dan bisa bekerjasama dalam pengabdian masyarakat ini untuk memberikan kesejahteraan bagi orang lain khususnya di daerah Sungai Bakung Kabupaten Banjar Kalimantan Selatan, serta tim pengabdian. 


\section{DAFTAR PUSTAKA}

Andriani, Lili, dkk. 2020. Peningkatan Kemandirian Ekonomi Ibu Rumah Tangga melalui Demonstrasi Pembuatan Sabun Cuci Piring. MARTABE: Jurnal Pengabdian Masyarakat Vol 3 No 1 Tahun 2020. Hal 95-101.

Arifianto, Chandra Fitra, dkk. 2020. Peningkatan Kapabilitas Teknologi dalam Menghadapi Era Disrupsi pada Generasi Milenial melalui Webinar. BAKTI BANUA: Jurnal Pengabdian Kepada Masyarakat Volume 1 No. 2 November 2020. Hal 89-94.

Nurhikmah, dkk. 2020. Kewirausahaan dengan Mengangkat Potensi Unggulan Daerah di Kecamatan Loksado, Kabupaten Hulu Sungai Selatan Kalimantan Selatan Tahun 2018. BAKTI BANUA: Jurnal Pengabdian Kepada Masyarakat Volume 1 No. 2 November 2020. Hal 84-88.

Pratomo, Adi. Dkk. 2018. Optimasi E-Commerce dengan Penerapan Teknik SEO (Search Engine Optimization) untuk Meningkatkan Penjualan pada UKM Nida Sasirangan. Jurnal Impact: Implementation and Action Volume 1, Nomor 1, 2018. Hal 35-47.

Ranti, Mayang Gadih dan Susilawati, Erni. 2019. Shasira Craft, Usaha Kerajinan Kain Perca Sasirangan sebagai Upaya Pemberdayaan Ibu-Ibu Warga Perumahan Seribu, Kecamatan Martapura, Kabupaten Banjar, Provinsi Kalimantan Selatan. Jurnal Pengabdian Kepada Masyarakat MEDITEG Volume 4, Nomor 2, Desember 2019 Hal 32-41.

Soegoto, dkk. 2020. Meningkatkan Peran Ibu Rumah Tangga dalam Pengelolaan Keuangan. Jurnal Pengabdian dan Pemberdayaan Masyarakat Volume 4, No. 1 Maret 2020. Hal 141 -148. 